\title{
A 40-Year Story of River Sediment at Mount St. Helens
}

The 1980 eruption of Mount St. Helens in Washington State unleashed one of the largest debris avalanches (landslide) in recorded history. The debris avalanche deposited 3.3 billion cubic yards of material into the upper North Fork Toutle River watershed and obstructed the Columbia River shipping channel downstream. From the eruption on May 18, 1980, to September 30, 2018, the Toutle River transported a total of about 405 million tons of sediment into the lower Cowlitz River-enough to bury downtown Portland, Oregon, to a depth of 300 feet. Excluding the massive sediment load from the eruption itself, from October 1, 1980, to September 30, 2018, the Toutle River transported more than 248 million tons of sediment, or an average of 6.5 million tons per year.
Increased flood risk to downstream communities is managed by a sediment retention structure, grade building structures, berms, levees, and dredging. Near-real-time monitoring of streamflow and sediment yield is important for effective management of these dynamic mitigation efforts. Since the sediment retention structure began trapping sediment in November 1987, the Toutle River has transported on average 2.8 million tons of sediment per year into the lower Cowlitz River. This is still 10 times greater than pre-eruption levels, with higher sediment transport potentially approaching 50 to 100 times greater during storms. Despite the eruption lasting only a few hours, the socioeconomic effects and mitigation measures for the region continue into the 21 st century.
Photograph of the North Fork Toutle River eroding the 1980 debris avalanche resulting from the eruption of Mount St. Helens. Photograph by Adam Mosbrucker, U.S. Geological Survey.

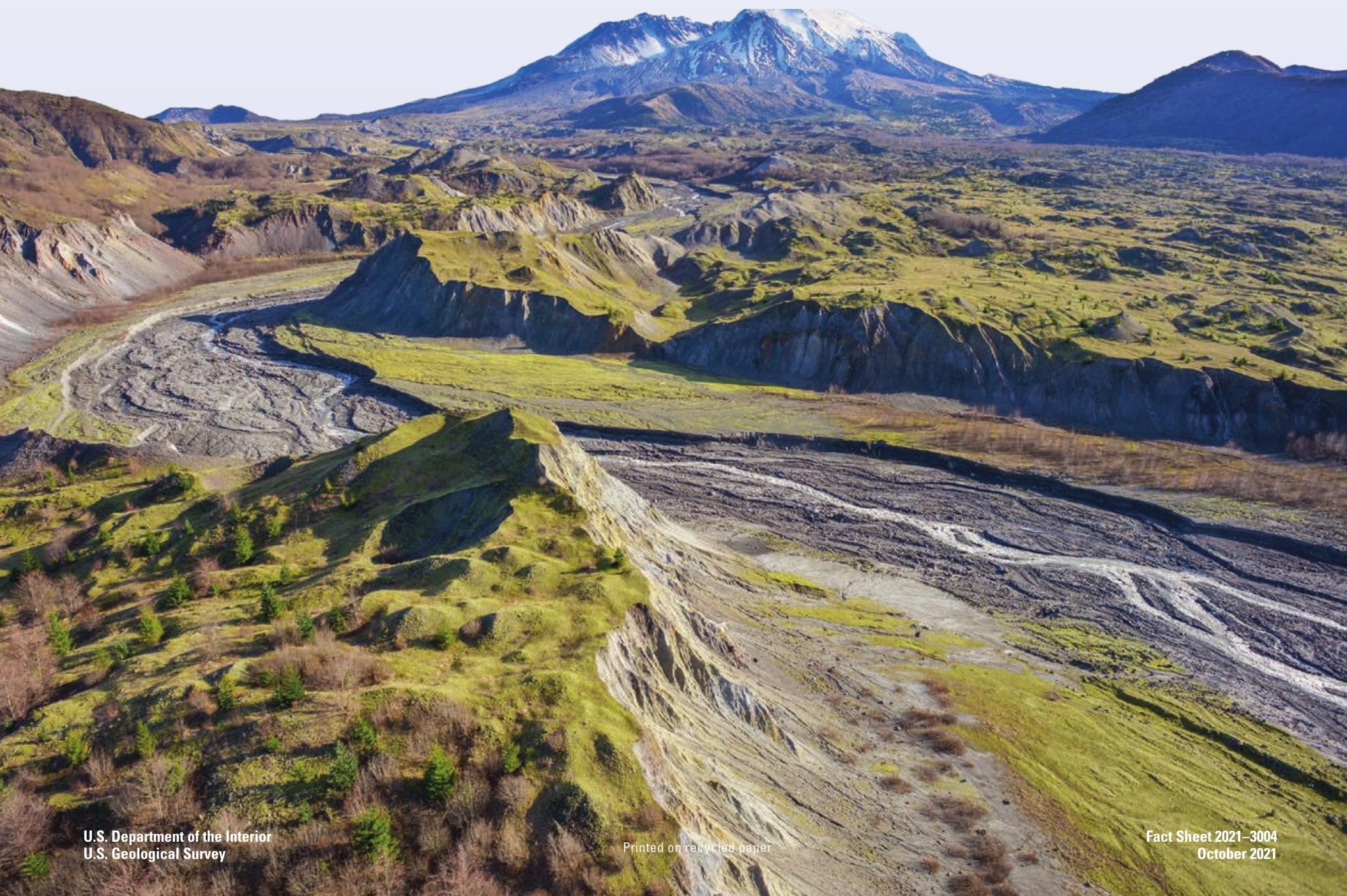




\section{River Valleys Smothered by a Volcanic Eruption}

The eruption of Mount St. Helens on May 18, 1980, generated one of the largest landslides, known as a debris avalanche, in recorded history-3.3 billion cubic yards, enough to fill 1 million Olympic-size swimming pools. The volcano lost more than 1,300 feet of elevation when the mountain's top and north flank collapsed and toppled, first northward and then mostly westward. The resulting volcanic debris was spread nearly 20 miles from the volcano. Many surrounding tributaries were partially blocked by this debris avalanche, which filled 23 square miles $\left(\mathrm{mi}^{2}\right)$ of the upper North Fork Toutle River valley to an average depth of 150 feet and as much as 500 feet locally. The debris avalanche sediment mixed with 170 million cubic yards $\left(\mathrm{yd}^{3}\right)$ of glacial ice and snow, as well as river and groundwater, to generate a massive volcanic mudflow known as a lahar-a mixture of water, mud, and volcanic rockthat traveled more than 70 miles along the river toward the Columbia River. Smaller lahars also ran down the South Fork Toutle River from the west flank of the volcano and the Muddy River from the southeast flank. These lahars substantially increased flood risks to downstream communities owing to deposited sediment on the beds of the lower Cowlitz and Columbia Rivers.

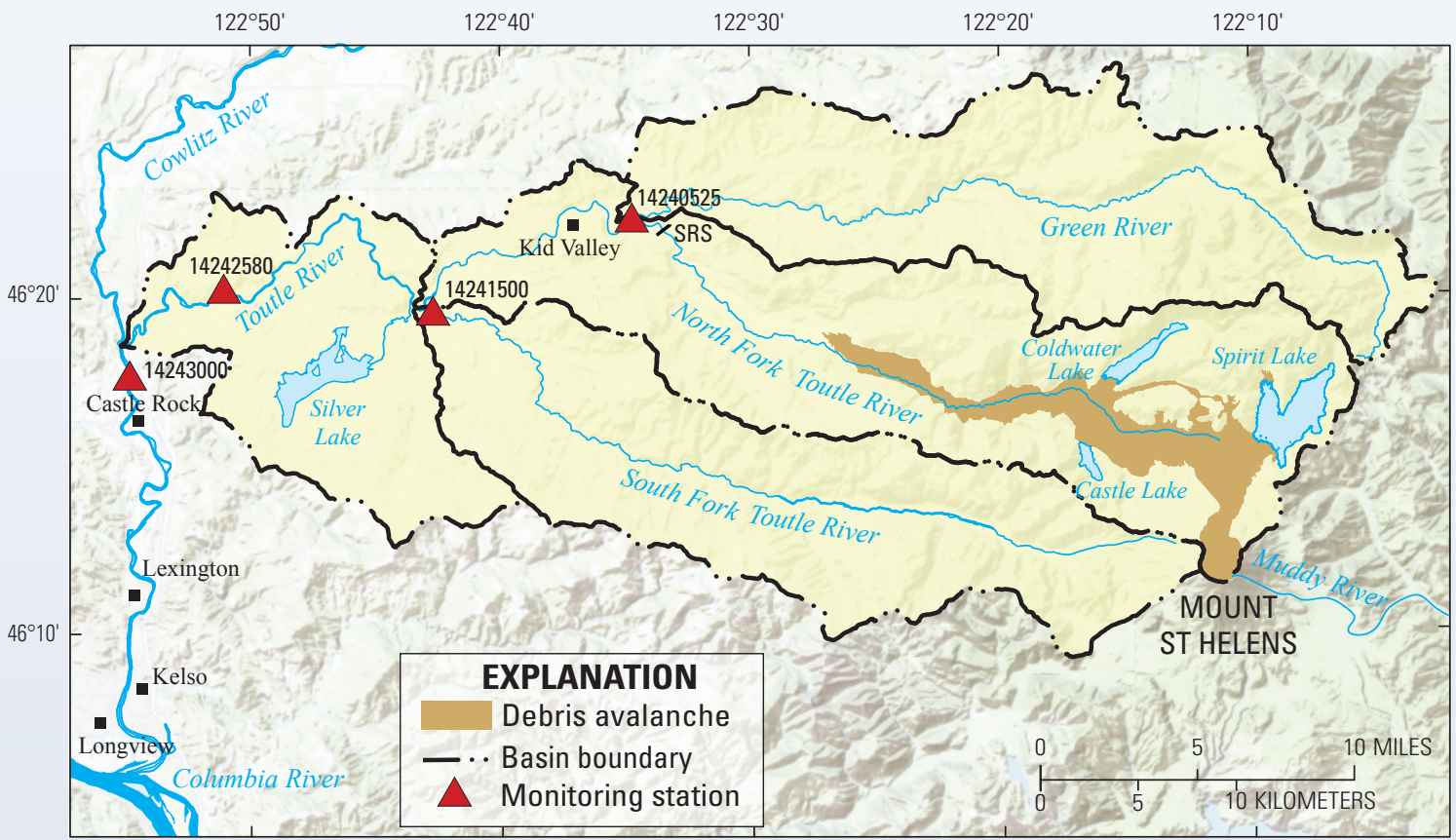

Base map source: USGS

\section{Three Main Sources of River Sediment}

The 20-mile-long debris-avalanche deposit supplies most of the sediment and the North Fork Toutle River continues to erode the deposit. Over time, the channel bed elevation has generally stabilized. Sediment is now captured primarily by bank erosion owing to channel widening, where the channel width increases more than the distance to the channel bed.
Intense rainfall events can generate small debris flows or erode sediments from all stretches of the Toutle River Basin streambanks, riverbeds, and surrounding storage areas as rivers rise and divert flow into new channels, sending newly eroded suspended sediment downstream.
Map showing tributaries within the Toutle River Basin, monitoring stations, sediment retention structure (SRS), and communities affected by sediment.
The Mount St. Helens crater supplies sediment via debris flows, rockfalls, and glacial-melt-induced floods in the headwaters of the North Fork Toutle River, supplying additional material to the debris avalanche deposit for subsequent erosion.

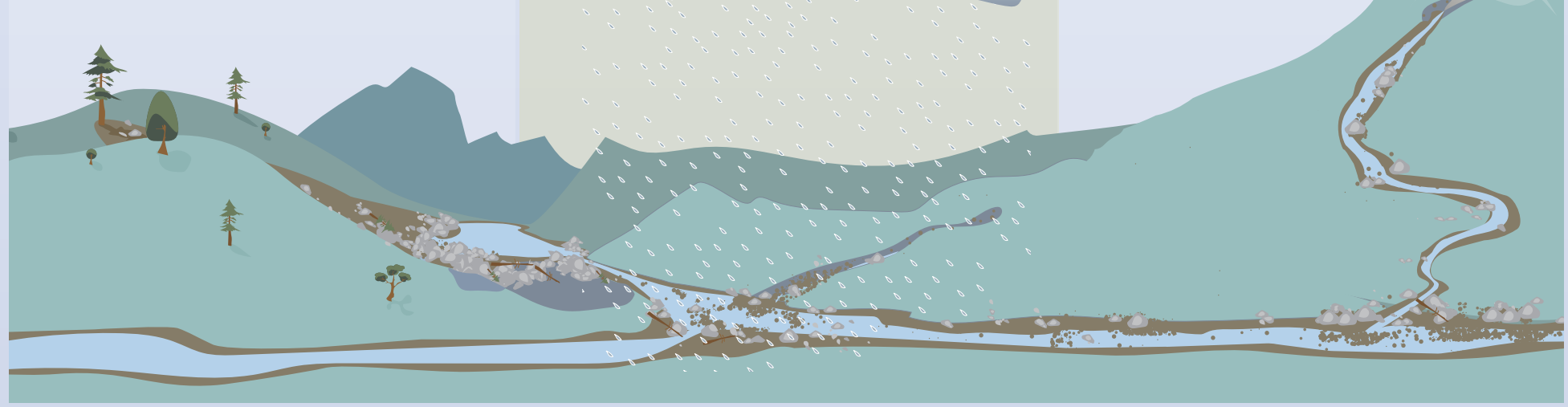




\section{How is Sediment Load Measured?}

Measuring sediment transported by rivers is usually done by lowering specially designed samplers into the stream. Once samples are collected, they are submitted for laboratory analysis. Samples are commonly collected during storms when sediment movement is greatest. Inclement weather and unpredictable storms, along with fast-flowing water, rising river depths, and large floating woody debris, can make sampling challenging. Monitoring sediment, in yearly and longer time scales, provides the best insight as to how sediment loads change by the day, month, or year. With that understanding, the nearly 40 -yearlong record at the Toutle River (station 14242580) is one of the longest sediment time-series datasets in the world. Such long-term sediment data are used to understand the landscape evolution of the Toutle River valley and assess sediment mitigation efforts.

Computing a continuous time series of daily, monthly, and annual sediment load requires repeat measurements of sediment transported by a river. Sediment load is the amount, or mass, of sediment that moves past a monitoring station in a specified period and is typically reported in units of tons per day. Sediment moves downstream as either suspended-sediment load (finer sediments kept suspended in the water column by turbulent forces) or as bedload (coarser sediments that move along the riverbed).

Quantifying suspended-sediment load (typically about three to four times the amount of bedload) requires two measurements - streamflow and suspended-sediment concentration. Streamflow (reported in cubic feet per second) refers to how much water is flowing in the river, and it is computed using water depth and velocity measurements. Suspended-sediment concentration (reported in milligrams per liter) refers to how much sediment is mixed in with the flowing

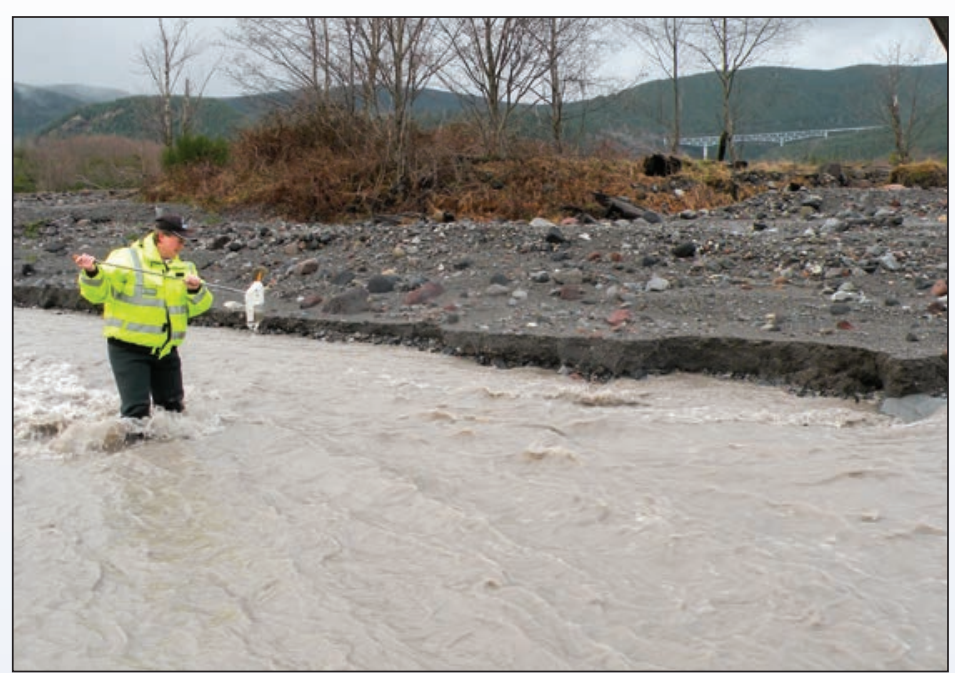

Photograph of Tami Christianson taking a sample from the Toutle River using a handheld suspended-sediment sampler. Photograph taken December 14, 2010, by Emily Roeder, U.S. Geological Survey volunteer.

water. The river is then sampled to determine the average concentration of suspended sediment by lowering a specially designed sampler through the water column at multiple locations across the river. The product of streamflow and suspendedsediment concentration is used to compute suspended-sediment load in tons per day.

Other techniques used to increase accuracy and completeness of sediment-load records when manual samples cannot be collected are automated pumping samplers; instream turbidity sensors, which measure water clarity; acoustic backscatter devices, which measure sound attenuation owing to particulate matter in the river; and (or) time-lapse cameras, which measure water color.

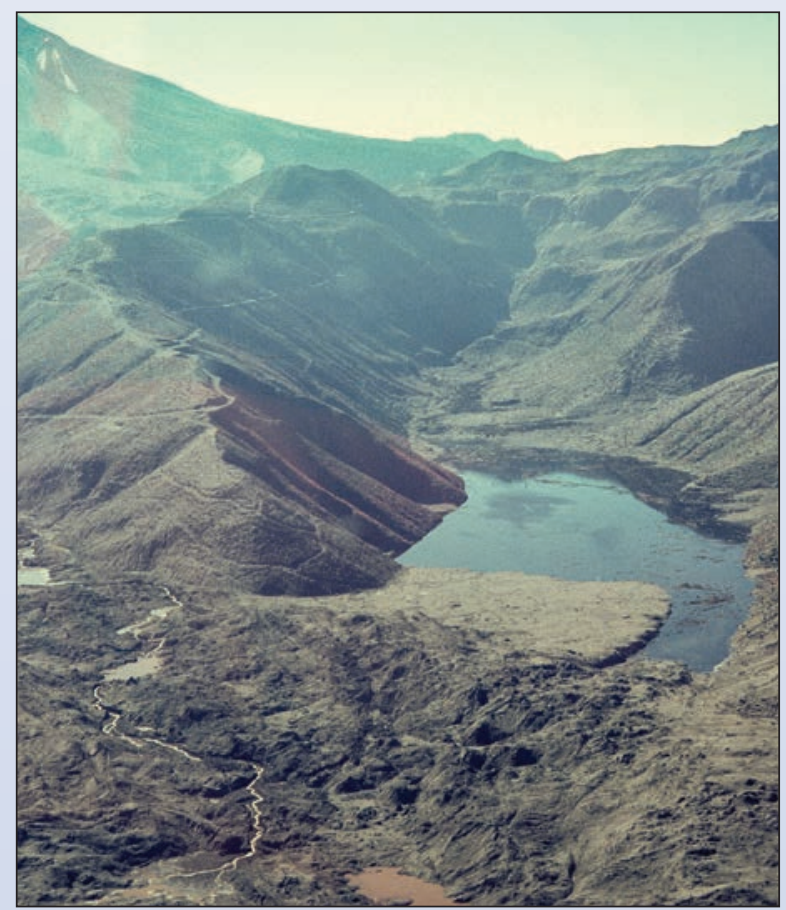

Aerial photograph of sediment partially filling and blocking Castle Lake. Photograph taken in September 1980 by Norm Dion, U.S. Geological Survey.

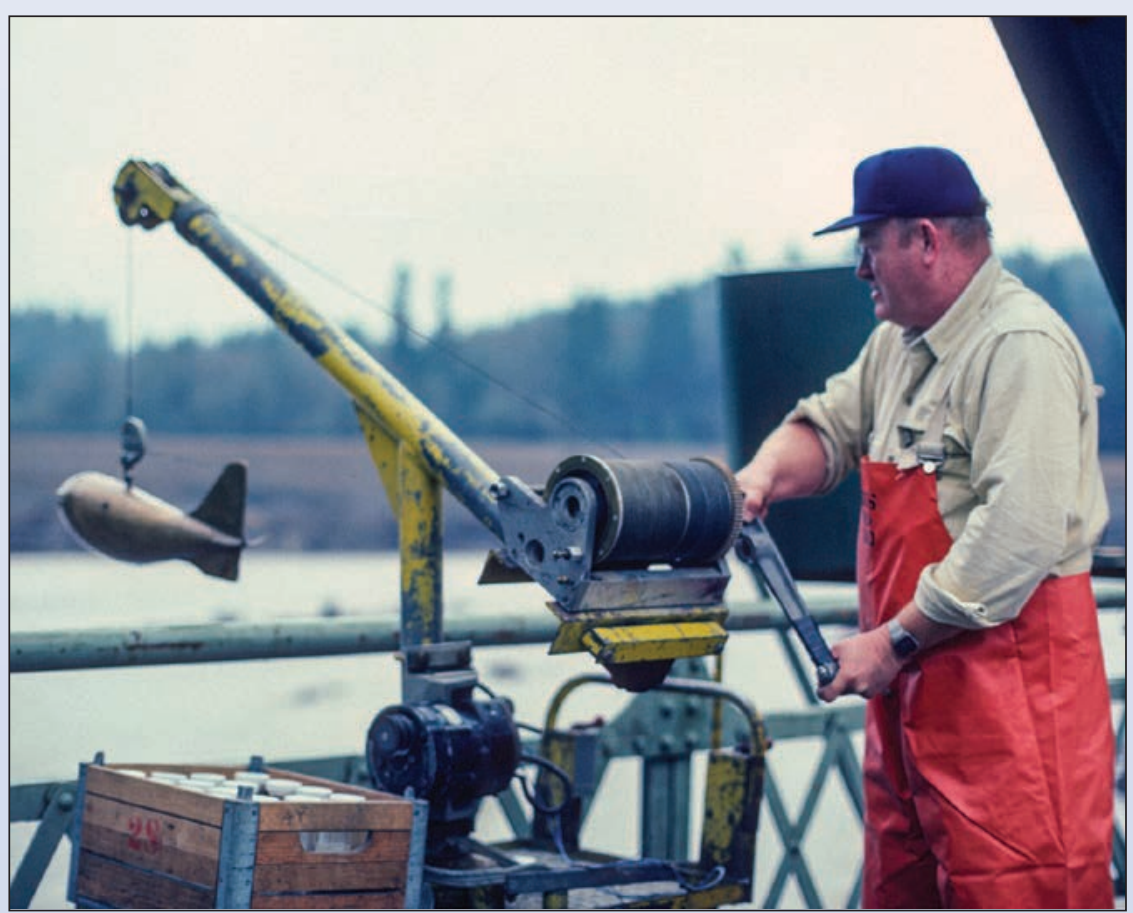

Photograph of Al Onions sampling Toutle River sediment using a cable-deployed suspended-sediment sampler. Photograph taken December 2, 1982, by Lyn Topinka, U.S. Geological Survey. 


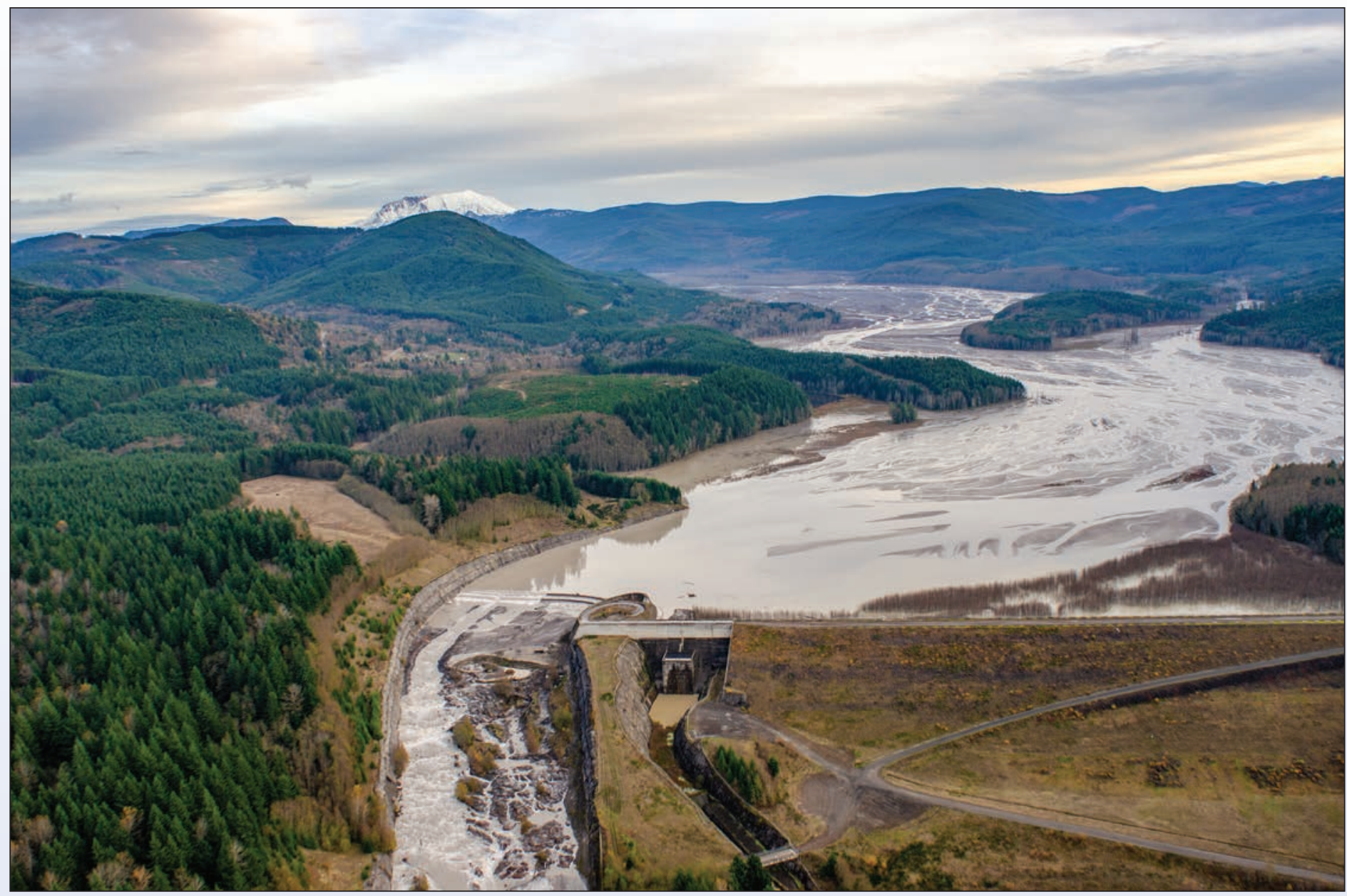

Photograph of the sediment retention structure (SRS) on the North Fork Toutle River after the 2012 spillway was raised. View is upstream to the east. Photograph by Adam Mosbrucker, U.S. Geological Survey.

\section{How Has River Sediment Been Managed?}

Excess river sediment presents both immediate and longterm hazards to downstream communities and aquatic habitats, and despite extensive effort over the past four decades, these hazards persist. Sediment management at Mount St. Helens has incurred greater costs than any of those resulting from the direct impacts of the eruption.

In response to immediate sedimentation hazards, the U.S. Army Corps of Engineers (USACE) mobilized extensive river dredging operations in the Toutle, Cowlitz, and Columbia Rivers to restore channel capacity. The lahars produced by the May 18, 1980 , eruption reduced the water-carrying capacity of the lower Cowlitz River to less than 10 percent of its former capacity by depositing 44 million $\mathrm{yd}^{3}$ of sediment on its bed. Upon reaching the Columbia River, these lahars deposited an additional 59 million $\mathrm{yd}^{3}$ of sediment that decreased channel depth from 40 to 14 feet along 10 miles of river and trapped ocean-bound vessels in ports upstream. The USACE also excavated outlets into the North Fork Toutle River from Spirit, Coldwater, and Castle Lakes, which were blocked by the debris-avalanche deposit. The outlets help prevent catastrophic dam failures and consequent releases of massive floods and lahars.

Recognizing a long-term hazard, the USACE built a large sediment rention structure (SRS), on the North Fork Toutle River that is designed to trap 258 million $\mathrm{yd}^{3}$ of sediment in the upper valley over a 50 -year period. The SRS is a 2,300 -foot-long, 180 -foot-tall, earthen structure completed in 1989 at a cost of $\$ 65$ million. Located on the North Fork Toutle River upstream from its confluence with the Green River, sediment began depositing behind or just upstream from the SRS as early as fall of 1987, at which time the trapping efficiency (the amount of sediment contained versus the amount that was delivered past the structure) was about 90 percent. But as sediment has accumulated behind the structure, its trapping efficiency has fluctuated and declined. At times, the sediment trapped behind the SRS has been a sediment source instead of an area of deposition. The USACE currently uses an adaptive-management strategy to mitigate the sediment hazard. This strategy includes upstream grade-building structures and berms (built in 2010 at a cost of $\$ 4$ million) and plans for incremental spillway raises as needed (the first one was completed in 2012 at a cost of $\$ 4.5$ million). Dredging of the lower Cowlitz River will continue to be used on a limited, as-needed basis to maintain channel capacity in flood-prone areas.

Adaptive sediment management requires extensive monitoring of sediment sources, erosion rates, and transport processes through continuous study. The knowledge gained from long-term monitoring at Mount St. Helens provides historical perspective and helps assess effects on society and aquatic habitat in the Toutle River Basin. 


\section{Toutle River Sediment Data from 1980 to 2018}

The Toutle River sediment load is substantially higher than all other rivers that originate from the western Cascade Range and surpasses basins with much larger drainage areas. Despite mitigation measures, long-term monitoring shows that 40 years after the May 18, 1980, eruption of Mount St. Helens, Toutle River suspended-sediment load (1988-2018 average) remains about 10 times greater than prior to the eruption. However, episodic large floods can transport 50 to 100 times more sediment.

During the first 7 years after the eruption (1980-87), enormous amounts of sediment were transported down the Toutle River to the confluence with the Cowlitz River and farther downstream to the Columbia River. These large amounts of sediment load subsided after 1987 when the construction of the SRS was complete, but the amounts remain greater in comparison to loads from other western Cascade Range rivers. Loads for 1981-87 totaled 161 million tons, about twice as much as the 87 million tons transported during the subsequent 31 years (1988-2018). Since 1981, the Toutle River has transported an average of 6.5 million tons of sediment per year, which is more than any other river in the western Cascade Range. In total, the sediment volume from 1988 to 2018 would cover a football field to a height of 960 feet.

Yearly suspended-sediment loads in the Toutle River Basin can be graphically depicted and more easily compared by calculating the suspended-sediment yield in tons per square mile, a quotient of suspended-sediment load and basin area. Although high streamflow primarily drives greater sediment transport, the SRS has a substantial effect on annual Toutle River suspended-sediment yield. After an initial decline subsequent to the 1980 eruption, suspended-sediment yield remained elevated until the SRS began reducing downstream transport in 1988-89. Yields were near background levels in 1989, 1992-94, and 2001 owing to droughts and the effect of the SRS. The greatest 5 -year yield after 1989 occurred from 2005 to 2009 (totaling more than 48,000 tons per square mile), well after sediment had filled to the level of the SRS spillway. Upon reaching the

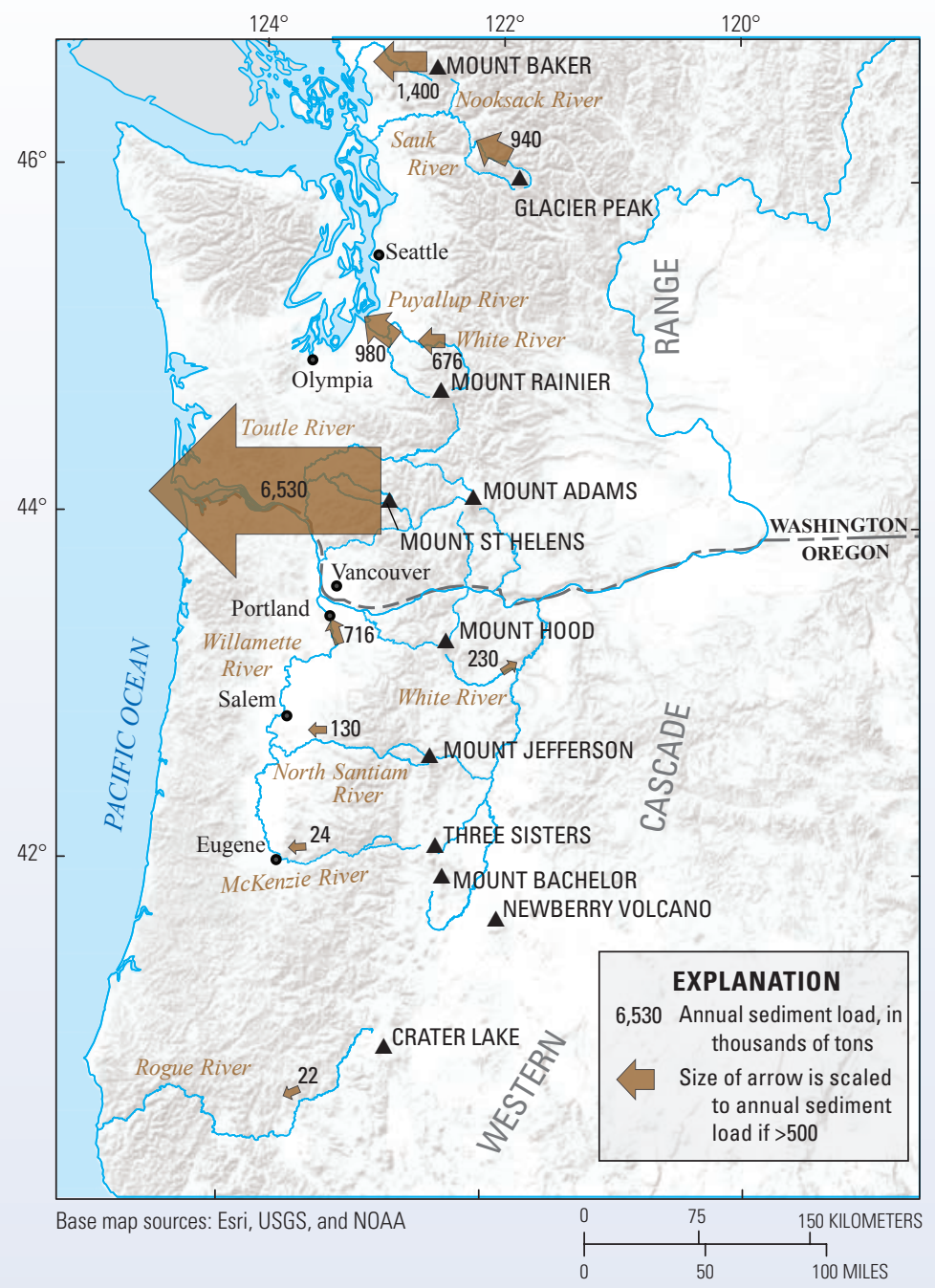

Map showing annual suspended-sediment load, in thousands of tons, for rivers in western Washington and Oregon with headwaters mostly from volcanoes in the western Cascade Range. Sediment load data for all non-Toutle Basin rivers were collected and averaged for 2 to 22 complete or partial water years, spanning from 1964 to 2016.
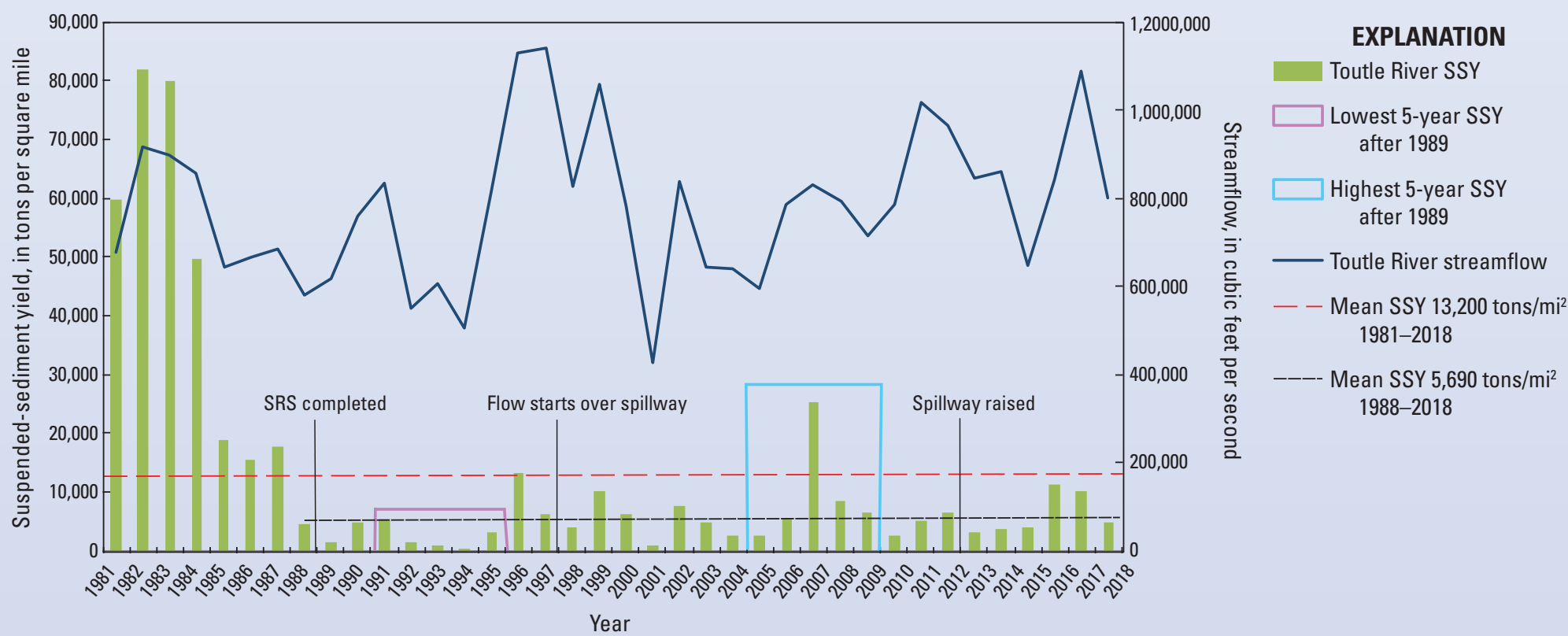

Graph of annual suspended-sediment yield (SSY) in tons per square mile (mi²) and streamflow (annual cumulative daily mean streamflow in cubic feet per second) data for the Toutle River at Tower Road (station 14242580) for water years 1981-2018. A water year begins 0 ctober 1 and ends the following September 30 (for example, water year 2018 is from October 2017 through September 2018). SRS refers to the sediment retention structure. 
spillway, some of the newly eroded sediment could bypass the structure and move farther downstream. In 2012, the spillway was raised, and suspended-sediment yields declined again until large storms mobilized high amounts of sediment in water years 2016 and 2017 (a water year begins October 1 and ends the following September 30). Overall, the highest yields occur during large floods. During the five highest years of sediment transport (1996, 1999, 2007, 2016, and 2017) since the SRS was completed in 1989, an average of 25 percent of the annual yield was transported in just one flood.

If multiple monitoring stations are located along a river or its tributaries, scientists can evaluate how sediment moves through a basin. Since 1986, the North Fork Toutle River (station 14240525) has supplied about 60 percent of the suspendedsediment load delivered from the Toutle River Basin. Sediment transported by the South Fork Toutle River (station 14241500) represents about 12 percent of the Toutle River sediment load. The remaining 28 percent of the load passing the Toutle River monitoring station comes from localized storage, bank erosion, and smaller tributary inputs. As sediment from the Toutle River moves downstream, much of the fine sand and smaller sized sediment (about 80 percent of the load) washes through to the Columbia River, whereas coarse sand and larger sediment (about 20 percent of the load) settles on the bed of the lower Toutle, Cowlitz, and Columbia River channels. This coarser sediment typically mobilizes only during relatively brief periods when high river flows occur.

\section{Societal and Economic Impacts}

Despite the May 18, 1980, eruption lasting only several hours, the socioeconomic impacts continue into the 21 st century. After 40 years, only about 20 percent of the 1980 debrisavalanche deposit has been eroded and removed by the North Fork Toutle River. Although much of the remaining sediment will likely remain permanently sequestered from the effects of river transport, there still exists within the active and migrating

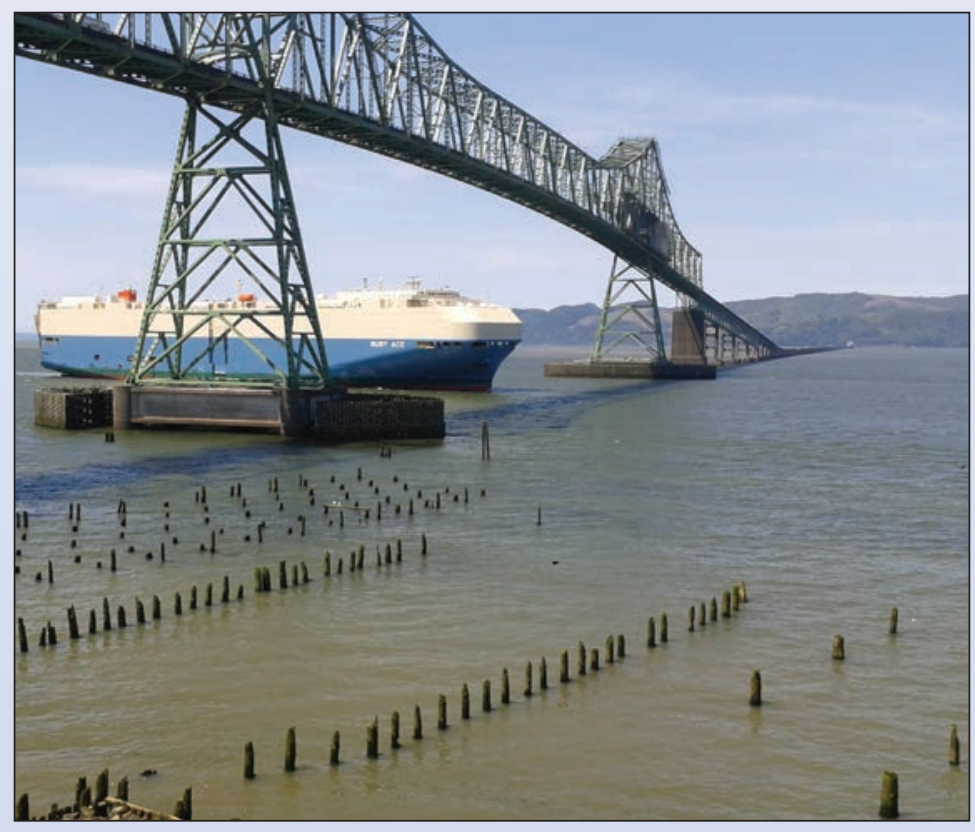

Photograph of a cargo ship carrying new automobiles entering the mouth of the Columbia River by passing under the Oregon-to-Washington bridge at Astoria, Oregon. Photograph by Mark Uhrich, U.S. Geological Survey.

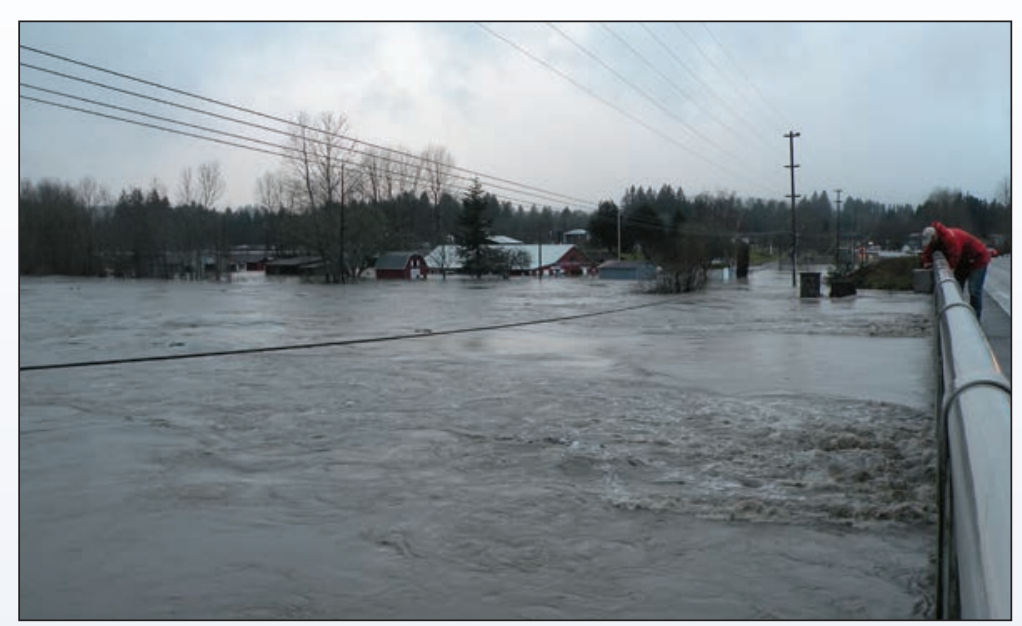

Photograph of the flooding Cowlitz River in January 2009 at Castle Rock, Washington. Photograph by Kate Norton, U.S. Geological Survey.

corridor of the North Fork Toutle River an enormous supply of sediment to be eroded and transported downstream to, and past, the SRS.

The greatest societal impact of deposited sediment is usually far from the volcanic source, and communities and infrastructure situated in lowlands are typically affected by the excess sediment. Perhaps the greatest enduring impact of excess sediment transport from Mount St. Helens is the increase in flood risk to downstream communities. More than 50,000 people living along the Cowlitz River in the Washington towns of Castle Rock, Lexington, Kelso, and Longview could be negatively affected by future flooding, in addition to revenue losses because of business disruptions.

The marine cargo industry is also negatively affected by increased sedimentation of the Columbia River shipping channel. The Port of Longview authorities currently plan to spend

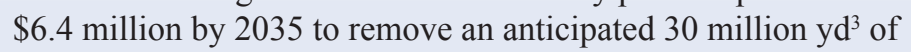
sediment that will impede their shipping berths. The Columbia River is a major regional and global gateway for wheat, soy, grains, wood, and automobiles. Any interruption in this commerce adversely affects the financial well-being of the entire region.

To protect and preserve the societal vitality and economic progress of these communities, the USACE has projected it will allocate $\$ 400$ million to combat the sediment-laden waters flowing from Mount St. Helens until 2035, when the congressionally mandated 50 -year flood-control plan expires. Adaptive management requires continued sediment monitoring to update hazard assessments and to reliably guide future mitigation efforts. However, 40 years of sediment monitoring and research suggests that expenditure to control the effects of oversupply of sediment in the Toutle and Cowlitz Rivers will endure well beyond 2035 .

\section{For more information:}

Sediment data can be accessed in USGS State Water Data Reports, Water Supply Papers, and the National Water Information System. Additional resources are available at https://doi.org/10.3133/fs20213004.

By Mark A. Uhrich, Kurt R. Spicer, Adam R. Mosbrucker, Dennis R. Saunders, and Tami S. Christianson Edited by Aditya Navale, Phil Frederick, and Monica Erdman Layout and design by Kimber Petersen 